Jurnal MAKSIPRENEUR, Vol. IV, No. 1, 2014, hal. 139 - 153

\title{
PENGEMBANGAN KAPASITAS DAN KELEMBAGAAN KELOMPOK SIMPAN PINJAM DI DESA SENDANGARUM, MINGGIR, SLEMAN
}

\author{
Yuli Kurniyati, (yulikurniyati@yahoo.co.id) \\ Fakultas Ekonomi, Universitas Proklamasi 45 Yogyakarta \\ Bening Hadilinatih, (linatih@yahoo.com) \\ FISIPOL, Universitas Proklamasi 45 Yogyakarta
}

\begin{abstract}
Padukuhan Singojayan savings groups and Mawar savings group and loans Toglengan, village Sendangarum Minggir sub district, Sleman, has the problem: 1). The weakness of the institution ala spects of group organization, yet have a clear institutional rules, 2) Still Weak aspects of group administration, administrative and financial management systems are still very simple, 3) Low skills of administrators in the management of savings and loans, the ability of the management of the organization low group 4). The low activity of productive business (entrepreneurship) members. Metode approach used to over come the problem of partner is counseling, training and mentoring. The training consists of training the administrative and book keeping group, institutional management and Cooperative Training, Computer Training \&Practice (Ms.Word \& Ms Excel), entrepreneurship training and counselling on procedures for the preparation of Planning and Budgeting. Participants of the training consists of aboard of each pathners group. Activity targets are to be achieve done achactivity are as follows: 1) Extension of the procedure for the preparation of Planning and Budgeting; to improve the knowledge and ability to prepare a document for Planning and Budgeting group. 2). Administration and book keeping training group; to improve the knowledge and skills of participants in the financial administration and book keeping savings group savings and loan accounting. 3). Institutional and cooperative management training; that the boardhad knowledge of the institutional and cooperative management. 4) training and practice computer; to improve the knowledge and skills to use computers to support the administration of savings groups. 5) entrepreneurship training; to improve the understanding of entrepreneur shipand increased interest, the spirit of entrepreneurship, as well as an increase in entrepreneurial activities of the participants. While the targets to begenerated from the mentoring activities are: 1) Savings Group are orderly administration includes administrative requirements of the organization and administration book keeping.2) Enterpreneurship spirit and motivations 3). Improving the skills of administrators in operating a computer for administrative support groups. 4). Establishment of a complete annual financial statements (Balance Sheet report, Net Income Reports, Cash Flow Statement) as part of the management performance report submitted in the annual RAT5). Completion of the Planning and Budgeting, SOP savings and loans, the rights and obligations of members, Job description pengurus. Hasil
\end{abstract}


already achieved in this activity is already implemented entrepreneurship training, administration and computer groups to improve understanding and skills committee. To each group was given the help of computer/notebook for each administrative group support. To follow up training next plan is for mentoring activities toeach groups.

Keywords: institutional management group. Entrepreneurship, administrative financial savings groups

\section{PENDAHULUAN}

Kelompok Simpan Pinjam (KSP) adalah lembaga keuangan yang menghimpun dan mengelola dana masyarakat dalam lingkup terbatas, sehingga usahanya memiliki karakter khas, merupakan usaha yang didasarkan pada kepercayaan (Chaniago, 1982). Dalam kelompok simpan pinjam, masyarakat berperan sebagai pemilik dan penilik lembaga keuangan (Zainuddin, 1997). Sebagai pemilik, anggota dan pengurus adalah pihak yang mengambil keputusan dan merumuskan program lembaga. Sebagai pemilik, mereka yang mengontrol pengelolaannya. Dengan partisipasi ini, Sumodiningrat, (1997) menyatakan bahwa pemupukan modal yang merupakan kunci dari pengembangan kelompok simpan pinjam muncul dari dalam sendiri, yakni dari masyarakat, oleh masyarakat. Tujuan lembaga ini adalah untuk menyediakan pinjaman yang murah, menciptakan modal bersama dan memperkuat kebersamaan dengan kegiatan utamanya menyelenggarakan tabungan dan pemberian pinjaman bagi anggotanya dengan syarat syarat yang mudah berdasarkan kepercayaan dan kekeluargaan. Dalam konteks yang lebih luas, Gunardi (1994) mengemukakan bahwa kelompokkelompok usaha simpan pinjam dapat berperan sebagai institusi mediasi antara lembaga penyalur kredit dan pemerintah dengan masyarakat lapisan bawah.

Dalam kegiatan pengabdian pada masyarakat ( IbM) yang dilakukan, Kelompok simpan pinjam yang dijadikan mitra adalah Kelompok Simpan Pinjam Padukuhan Singojayan dan Kelompok Simpan Pinjam "Mawar" dusun Toglengan di Desa Sendangarum, Kecamatan Minggir, Kabupaten Sleman, Daerah Istimewa Yogyakarta. 
Keberadaan kedua kelompok simpan pinjam tersebut sangat menunjang perekonomian anggotanya, terutama peranannya sebagai sumber pendanaan bagi para anggotanya, yang pada gilirannya akan berdampak pada kesejahteraan masyarakat pada umumnya. Kelompok pinjam juga dapat memberikan bantuan pinjaman kepada para anggotanya disaat anggota tersebut membutuhkan uang untuk pembiayaan sekolah, biaya pengobatan, dan lain sebagainya. Namun dari hasil analisis situasi, hasil observasi, dan diskusi dengan kedua Mitra, teridentifikasi bahwa kedua kelompok simpan pinjam tersebut menghadapi permasalahanpermasalahan utama yang perlu segera dipecahkan, yaitu:

1. Masih lemahnya aspek organisasi kelembagaan Kelompok. Kedua kelompok Belum memiliki aturan kelembagaan yang jelas yang dibakukan dalam Anggaran Dasar dan anggaran Rumah Tangga Kelompok simpan Pinjam.

2. Masih Lemahnya aspek administrasi kelompok. Jenis dan pengerjaan administrasi organisasi yang dilakukan kedua kelompok belum memadai demikian juga mengenai jenis dan pengerjaan administrasi keuangan masih sangat sederhana.

3. Masih rendahnya ketrampilan pengurus dalam pengelolaan simpan pinjam, yang ditandai dengan rendaknya kinerja pengurus, pengelolaan bersifat sederhana dan tidak menerapkan prinsip-prinsip manajemen. Upaya meningkatkan pengetahuan dan keterampilan juga mengalami kendala berupa terbatasnya orang atau institusi yang memberikan pelatihan dan terbatasnya dana untuk pengembangan sumberdaya manusia.

4. Masih rendahnya usaha produktif anggota. Rendahnya Kegiatan usaha produktif (kewirausahaan) anggota kelompok dalam memanfaatkan pinjaman dana untuk peningkatan kesejahteraan, hal ini disebabkan karena terbatasnya pemahaman tentang kewirausahaan.

Berdasarkan permasalahan yang dihadapi kelompok simpan pinjam tersebut maka kegiatan Pengabdian Pada Masyarakat ini dilaksanakan untuk memberikan bantuan dalam mengatasi permasalahan yang dihadapi, dengan memberikan penyuluhan dan ketrampilan bagi pengurus dan anggota kelompok dalam hal-hal berikut: 
1. Penguatan pemahaman tentang organisasi kelompok dan pengetahuan tentang tata cara penyusunan Anggaran dasar dan anggaran rumah Tangga (AD/ART) Kelompok simpan Pinjam (KSP). Dengan adanya AD/ART maka organisasi mempunyai dasar pijakan aturan kelembagaan yang jelas untuk menjalankan organisasinya.

2. Penguatan pemahaman dan ketrampilan tentang administrasi keuangan dan perkoperasian. Penguatan pengelolaan keuangan dengan fasilitasi penguatan administrasi dan pelaporan keuangan serta fasilitasi peningkatan simpanan anggota. Dengan mengetahui seluk beluk administrasi keuangan simpan pinjam dan koperasi beserta peraturan perundang-undangan yang berlaku, maka KSP akan semakin baik sesuai kaidah yang ditentukan oleh pemerintah

3. Peningkatan pengetahuan tentang manajemen kelembagaan bagi pengurus dalam melakukan pengelolaan simpan pinjam. Penguatan pengelolaan pinjaman dengan fasilitasi pembuatan aturan dan mekanisme penyaluran pinjaman, fasilitasi penentuan persyaratan pinjaman, fasilitasi pengelolaan pinjaman bermasalah, dan sebagainya. Penguatan manajemen dengan melakukan fasilitasi peningkatan kapasitas pengurus dan anggota kelompok dalam wadah kelompok ataupun manajemen. Dengan pemahaman manajemen kelembagaan yang baik maka diharapkan kinerja pengurus akan meningkat, pengelolaan Kelompok usaha simpan pinjam berkembang dan keswadayaan organisasi meningkat. .

4. Peningkatan pemahaman tentang kewirausahaan. Dengan pengetahuan kewirausahaan yang cukup diharapkan akan menumbuhkan motivasi kegiatan usaha produktif anggota kelompok usaha simpan pinjam.

\section{KAJIAN LITERATUR}

\section{Kelompok dan organisasi sebagai institusi masyarakat}

Dalam usaha meningkatkan taraf dan kualitas hidup masyarakat pedesaan perlu digali cara-cara pengelolaan usaha yang paling sesuai, salah satu potensi yang dapat dikembangakan adalah pembinaan kelompok-kelompok masyarakat sebagai media peningkatan taraf dan kualitas hidup mereka. Brown dan Moberg (Ruwiyanto,1988) mengungkapkan bahwa organisasi berada dalam dalam kontinum 
individu-masyarakat. Mereka berdua menyebutkan bahwa masyarakat itu merupakan gabungan dari komunitas. Komunitas merupakan gabungan dari organisasi. Organisasi merupakan gabungan dari kelompok, dan kelompok merupakan gabungan dari individu. Browm dan Moberg juga menyebutkan bahwa guna mempelajari individu dan kelompok, digunakan pendekatan yang mereka sebut pendekatan mikro, sedangkan guna mempelajari komunitas dan masyarakat perlu menggunakan pendekatan makro.

Kelompok masyarakat diharapkan bukanlah kelompok tanpa kemajuan, tetapi kelompok masyarakat harus berkembang menuju kepada perkembangan dan kemajuan. Untuk itu para anggota bisa diminta untuk mendefinisikan tahap-tahap perkembangan kelompok sebagai langkah yang akan ditempuhnya. Tahap-tahap tersebut akan menjadi acuan program pengembangan kelompok dan anggota untuk mencapainya secara bersama-sama (Karsidi, 1998).

Menurut Raharjo (1989) mendasarkan pada kelompok kepentingan ekonomi, ada tiga tahap kemajuan kelompok. Tahap pertama dapat disebut sebagai kelompok swakarsa, kemudian kelompok swakarya dan terakhir adalah kelompok mandiri. Kelompok yang berada dalam suatu tahapan diharapkan akan terus berkembang menuju ke tahapan berikutnya sehingga menjadi kelompok yang mandiri.

\section{Kelompok simpan pinjam sebagai embrio koperasi simpan pinjam}

Keberadaan kelompok simpan pinjam di wilayah pedesaan harus dikembangkan dan terus dibina sehingga diharapkan bisa berkembang menjadi koperasi simpan pinjam. Koperasi Simpan Pinjam Adalah koperasi yang bergerak di bidang simpanan dan pinjaman. Sesuai dengan pengertian koperasi, didalam koperasi selalu terdapat unsur-unsur sosial sekaligus unsur ekonomi. Walaupun kedua unsur tersebut berbeda, namun satu sama lainnya saling berkaitan menjadi satu kesatuan. (Rudianto,2006 :1). Koperasi adalah organisasi ekonomi yang harus memepertahankan kelangsungan hidupnya, bahkan kalau bisa terus dikembangkan. Agar dapat berkembang maka koperasi harus dikelola dengan manajemen yang profesional. 


\section{Akuntansi dan aktivitas Koperasi}

Tujuan didirikannya koperasi adalah untuk memberikan kesejahteraan dan manfaat bagi anggotanya dan masyarakat pada umumnya. Agar tujuan terebut dapat tercapai maka setiap koperasi harus mampu menghasilkan laba usaha yang harus dapat dilaporkan dalam Laporan Keuangan secara periodik dalam system akuntansi yang teratur dan terpercaya. Akuntansi adalah sistem informasi yang menghasilkan laporan kepada pihak-pihak yang berkepentingan mengenai aktivitas ekonomi dan kondisi suatu badan usaha. (Rudianto, 2005: 13).

Dalam proses menghasilkan informasi yang dibutuhkan oleh berbagai pihak yang berkepentingan, akuntansi harus melewati beberapa tahapan proses. Proses tersebut dimulai dari mengumpulkan dokumen dasar transaksi, mengklasifikasikan jenis transaksi, menganalisa, meringkasnya dalam catatan dan sampai dengan melaporkannya dalam bentuk laporan keuangan yang dibutuhkan; proses tersebut dinamakan siklus akuntansi.

\section{Macam Laporan Keuangan Koperasi}

Sesuai dengan standar akuntansi keuangan yang berlaku di Indonesia mulai tahun 2004 PSAK N0.27 tahun 2004, Laporan keuangan koperasi terdiri dari :

a. Perhitungan Hasil Usaha

Adalah suatu laporan yang menunjukkan kemampuan koperasi dalam menghasilkan profit dalam suatu periode akuntansi tau satu tahun. Laporan hasil Usaha harus merinci mengenai hasil usaha yang berasal dari anggota dan profit yang diperoleh dari aktivitas koperasi yang berasal dari bukan anggota.

b. Neraca

Dalam suatu daftar yang menunjukkkan posisi sumber daya yang dimiliki koperasi, serta informasi dari mana sumberdaya tersebut diperoleh

c. Laporan arus Kas

Adalah suatu laporan mengenai arus keluar masuknya kas di dalam suatu periode tertentu, yang mencakup saldo awal kas, sumber penerimaan kas, sumber pengeluaran kas dan saldo akhir kas pada suatu periode. 


\section{d. Laporan promosi Ekonomi Anggota}

Adalah Laporan yang menunjukkkan manfaat ekonomi yang diterima angggota koperasi selama suatu periode tertentu. Laporan tersebut mencakup 4 unsur, yaitu sebagai berikut:

1) manfaat ekonomi dari pembelian barang atau pengadaan jasa bersama.

2) Manfaat ekonomi dari pemasaran dan pengolahan bersama

3) Manfaat ekonomi dari simpan pinjam lewat koperasi

4) Manfaat ekonomi dalam bentuk pembagian SHU

Anggota koperasi diharapkan mengetahui dan memahami tentang Akuntansi koperasi sehingga bisa bersinergi dengan para Fungsionaris koperasi yang lain dalam mengembangkan koperasi.

\section{Kewirausahaan}

Kewirausahaan adalah kemampuan menciptakan sesuatu yang baru secara kreatif dan inovatif untuk mewujudkan nilai tambah(Overton, 2002). Kreatif berarti menghasilkan sesuatu yang belum pernah ada sebelumnya. Inovatif berarti memperbaiki/ memodifikasi/ mengem-bangkan sesuatu yang sudah ada. Nilai tambah berarti memiliki nilai lebih dari sebelumnya. Ada yang berpendapat bahwa istilah kewirausahaan itu merupakan singkatan dari: Kreatif, Enerjik, Wawasan luas, Inovatif, Rencana bisnis, Agresif, Ulet, Supel, Antusias, Hemat, Asa, Ambisi, Negosiatif. (Anonim 1, 2005). Sebenarnya, masih banyak lagi sifat-sifat yang harus dimiliki seorang wirausaha misalnya berani mengambil risiko dengan penuh perhitungan, mampu memanfaatkan peluang, komunikatif, mampu memasarkan, mampu bernegosiasi.

Seorang wirausahawan yang sukses harus memiliki tiga kompetensi pokok yaitu pengetahuan, keterampilan, dan sikap kewirausahaan. Ketiga kompetensi tersebut saling berkaitan. Kompetensi merupakan penguasaan pengetahuan, keterampilan, dan sikap. Pengetahuan adalah kumpulan informasi yang disimpan di otak dan dapat dipanggil jika dibutuhkan.Keterampilan adalah kemampuan menerapkan pengetahuan. Sikap adalah sekumpulan kualitas karakter yang membentuk kepribadian seseorang (Anonim 2, 2005). 


\section{II.METODE PELAKSANAAN}

Metode pelaksanaan yang digunakan dalam realisasi program Ipteks bagi Masyarakat ini adalah penyuluhan, pelatihan dan pendampingan, yang meliputi:

\section{Penyuluhan}

Penyuluhan dilakukan dengan metode ceramah dan diskusi tentang pentinggnya Anggaran Dasar Dan anggaran Rumah tangga (AD/ART) dalam organisasi serta tata cara penyusunan Anggaran Dasar Dan anggaran Rumah tangga. Dalam penyuluhan ini, setelah ceramah dilakukan maka dibuka sesi tanya jawab bagi yang kurang jelas. Penyuluhan ini dimaksudkan untuk memberi pemahaman bagi semua anggota kelompok tentang pentingnya AD/ART sebagai pedoman kelompok/organisasi untuk penguatan kapasitas kelembagaan/organisasi kelompok.

\section{Pelatihan}

Pelatihan diberikan kepada pengurus kelompok usaha simpan pinjam. Metode Pelatihan meliputi beberapa bentuk kegiatan, yaitu berupa ceramah, curah pendapat, permaian (games) serta praktek laboratorium belajar komputer. Metode pelatihan ini diberikan untuk memberi solusi atas permasalahan yang telah disepakati bersama mitra.

\section{Pendampingan}

Pendampingan adalah kegiatan yang bertujuan untuk memberikan penguatan terhadap proses implementasi konsep penyuluhan dan pelatihan yang telah dilakukan,mendampingi kelompok masyarakat dalam rangka supervisi kegiatan pembenahan administrasi pembukuan keuangan, ketrampilan menggunakan komputer,manajemen kelembagaan kelompok dan pendampingan dalam penyusunan AD/ART kelompok. Pendampingan dilakukan dengan melakukan petemuan secara berkala dengan kelompok masyarakat, dalam fase ini akan menjadi ajang konsultasi dan tukar pengalaman (sharing lesson-learned) . Pendampingan adalah kegiatan yang bertujuan untuk memberikan penguatan terhadap proses implementasi konsep penyuluhan dan pelatihan yang telah dilakukan. 


\section{HASIL DAN PEMBAHASAN}

Hasil yang telah dilakukan dan dicapai dalam pengabdian ini meliputi pengatasan masalah: Sistem administrasi dan pengelolaan keuangan yang masih sangat sederhana dengan pelatihan dan pendampingan administrasi pembukuan kelompok simpan pinjam, Masih rendahnya Kegiatan usaha produktif (kewirausahaan) anggota kelompok/koperasi dalam memanfaatkan pinjaman dana untuk peningkatan kesejahteraan dengan pelatihan kewirausahaan, masih rendahnya pemahaman tentang aturan kelembagaan dan status badan hukum koperasi yang belum dimiliki oleh masing-masing kelompok/koperasi dengan penyuluhan kelambagaan koperasi dan pendampingan penyusunan anggaran dasar /peraturan kelompoki, Tahapan Pelaksanaan kegiatan pengabdian masyarakat ini meliputi enam (6) kegiatan, yang terdiri dari :

\section{Sosialisasi rencana program kepada seluruh anggota dari masing-masing}

\section{kelompok simpan pinjam yang menjadi mitra,}

Sosialisi ini bertujuan memberikan gambaran dan pemahaman tentang kegiatan pelatihan dan pendampingan yang akan diberikan kepada mitra kelompok simpan pinjam. Kegiatan ini disambut baik oleh kedua mitra kelompok , terbukti dengan antusiasme anggota kelompok yang hadir untuk melakukan tanya jawab dan diskusi dengan tim pengabdi.

\section{Pelatihan administrasi dan pembukuan kelompok simpan pinjam}

Pelatihan administrasi dan pembukuan Kelompok Simpan Pinjam ini bertujuan agar para peserta pelatihan menguasai konsep dan mekanisme pengelolaan keuangan secara efisien dan efektif dengan pola pengelolaan administrasi keuangan serta administrasi umum kelompok simpan pinjam . Administrasi keuangan ini berkaitan dengan segala aktifitas keuangan yang ada di kelompok. Materi pelatihan kepada kelompok mitra terkait dengan cara penyusunan dan pemanfaatan catatan-catatan administrasi pembukuan seperti Buku Kas , Buku Piutang (Angsuran), Buku Simpanan, Buku Inventaris, Buku Laporan SHU dan Neraca, dll. Sedangkan Administrasi organisasi umum berkaitan dengan penyuluhan dan pelatihan tentang segala aktivitas organisasi secara umum yaitu 
pencatatan yang dilakukan atas segala aktivitas atau kegiatan kelompok yang dilakukan secara periodik. Buku-buku yang diperlukan dalam administrasi organisasi umum ini adalah :

1. Buku aturan kelompok

2. Buku Daftar Pengurus dan anggota

3. Buku daftar hadir pertemuan rutin (kegiatan lain)

4. Buku Notulen

5. Buku Tamu

Setelah kegiatan pelatihan Peserta pelatihan diharapkan dapat membenahi administrasi umum maupun administrasi keuangan di masing -masing kelompoknya, sehingga pencatatan seluruh aktivitas organisasi kelompok secara umum maupun yang berkaitan dengan keuangan dapat diadministrasikan secara tertib.Sehingga pada akhir periode pengurus dapat menyusun laporan kinerja secara lengkap.Peserta pelatihan juga dapat memahami dan mengaplikasikan standar operasional pembagian SHU Koperasi. Sehingga dengan pelatihan ini diharapakan dapat mengatasi permasalahan Sistem administrasi dan pengelolaan keuangan masih sangat sederhana di kedua mitra kelompok simpan pinjam. Outcame pelatihan administrasi dan akuntansi koperasi adalah peningkatan pengetahuan dan ketrampilan peserta dalam pengelolaan administrasi umum dan keuangan kelompok .

Evaluasi Pelaksanaan Pelatihan dilakukan dengan melakukan Pretest (sebelum Pelatihan dilaksanakan) dan Post Test (setelah Pelatihan dilaksanakan). Pretest dan Postest dilakukan dengan menugaskan peserta untuk mengisi kuesioner yang berisi kalimat penyataan mengenai administrasi kelompok simpan pinjam dengan pilihan jawaban yang disediakan. Kalimat pernyataanpernyataan yang diberikan dimaksudkan untuk mengukur kemampuan peserta di bidang administrasi dan akuntansi koperasi

Setelah mengikuti pelatihan terdapat peningkatan pengetahuan tentang administrasi dan akuntansi koperasi, hal ini terlihat rata-rata persentase peserta yang menyatakan memahami materi yang diberikan sebesar 85,94\%. Meskipun rata-rata masih terdapat $14,06 \%$ peserta yang belum dapat memahami materi 
yang diberikan. Untuk menambah pemahaman dan ketrampilan peserta pelatihan akan dilakukan pendampingan kepada kedua kelompok mitra, sebagai kelanjutan dari pelatihan.

\section{Pelatihan kewirausahaan}

Pelatihan Kewirausahaan dirancang untuk mendorong minat peserta sekaligus mempersiapkan peserta untuk menjadi wirausaha. Dengan berbagai latihan, diharapkan peserta dapat mulai membangun usaha, dari usaha-usaha yang sederhana hingga akhirnya mereka lebih berani memulai usaha yang lebih besar dan lebih komplek . Keterampilan-keterampilan yang bersifat soft skill, yang berhubungan dengan karakter seorang entrepreneur perlu dibangun disini. Karakter-karakter itu secara umum adalah berani mengambil inisiatif dan risiko, terbuka dan mampu mengungkapkan isi hati dan pikiran, persuasif, pemimpin yang bertanggungjawab, pekerja keras, menjunjung tinggi nilai-nilai kejujuran, dan seorang yang mampu melihat jauh ke depan.

\section{Penyuluhan tata cara pengesahan Badan Hukum Koperasi}

Kegiatan penyuluhan tata cara pengesyahan Badan Hukum Koperasi ini dirancang untuk memberikan pemahaman peserta tentang proses pengesahan badan hukum koperasi dan mekanisme pengajuan status badan hukum koperasi. Materi penyuluhan yang diberikan meliputi: Koperasi dan dasar hukumnya, Persiapan mendirikan koperasi, Rapat pemben-tukan koperasi, Anggaran dasar Koperasi dan Tata cara Pengesahana Badan Hukum Koperasi.

Para peserta terlihat antusias mendengarkan penjelasan yang diberikan oleh tim Pengabdi. Masing-masing pengurus kelompok mitra tergugah untuk segera mempersiapkan segala persyaratan yang diperlukan dalam proses pengesyahan badan hukum koperasi. Meskipun di kedua kelompok mitra masih terdapat kendala dari sisi jumlah anggota yang masih di bawah 20 orang.

\section{Pelatihan dan praktek komputer}

Pelatihan dan praktek komputer ini bertujuan untuk meningkatkan pengetahuan dan ketrampilan menggunakan komputer untuk menunjang kegiatan administrasi kelompok simpan pinjam. Materi pelatihan meliputi program komputer office: MS. Word dan Ms. Excel. Peserta pelatihan sangat 
antusias mengikuti pelatihan dan praktek komputer, hal ini dapat dilihat dari antusiasme dari seluruh peserta dalam mengajukan pertanyaan pada sesi praktek komputer. Sebagian besar peserta juga belum terampil mengoperasikan komputer.

\section{Pendampingan, kegiatan ini dilakukan sebagai tindak lanjut dari kegiatan pelatihan}

Kegiatan pendampingan merupakan tindak lanjut dari progam pelatihan kepada kedua mitra. Kegiatan pendampingan ini dilakukan satu minggu setelah pelatihan dengan kunjungan Tim Pengabdi ke lokasi mitra yaitu Kelompok Simpan Pinjam Padukuhan Singojayan dan Kelompok usaha simpan Pinjam "Mawar" yang berada di Dusun Toglengan, Desa Sendangarum, Kecamatan Minggir, Kabupaten Sleman. Penyusunan jadwal pendampingan ditentukan berdasarkan kesepakatan antara Tim Pengabdi dengan kelompok mitra.

Pendampingan dilakukan terkait dengan materi pelatihan yang meliputi kegiatan-kegiatan: Penataan administrasi dan pembukuan kelompok simpan pinjam, kewirausahaan, pendalaman pemahaman tentang tata cara pengesahan Badan Hukum Koperasi dan tata cara penyusunan Anggaran Dasar atau aturan main kelompok, serta praktek penggunaan computer. Pendampingan dilakukan selama 4 bulan secara intensif.

Setiap bulan masing-masing kelompok mempunyai jadwal pertemuan rutin dengan anggota masing-masing. Namun oleh karena adanya kegiatan pendampingan ini maka pertemuan kelompok diadakan seminggu sekali, dengan jadwal materi dan waktu pertemuan yang ditentukan berdasarkan kesepakatan antara anggota kelompok dengan Tim Pengabdi. Untuk pendampingan praktek computer, oleh karena kedua kelompok simpan pinjam belum memiliki computer, maka tim pengabdi memberi bantuan netbook untuk kelancaran operasional administrasi kelompok. Tim Pengabdi juga mendapingi kedua kelompok simpan pinjam dalam proses penyusunan laporan keuangan dan laoran SHU anggota yang diperlukan sebagai bahan laporan pertanggungjawan pengurus dalam RAT tahun 2012. 
Kegiatan pendampingan, sangat diperlukan agar mitra pelaksanaan kegiatan ini lebih memahami materi yang disampaikan dan dapat mengaplikasikannya dalam penataan dan penyempurnaan kegiatan kelpompok.

Hal-hal yang dicapai dari kegiatan pendampingan ini adalah:

a. Tumbuhnya semangat kewirausahaan dengan terbentuknya usaha produktif anggota.

b. Peningkatan ketrampilan pengurus dalam mengoperasikan computer dengan bantuan hibah computer (netbook). Untuk kelompok mitra, peningkatan ketrampilan tersebut diharapkan dapat memperlancar ketrampilan pengurus dan dapat menunjang kegiatan operasinal simpan pinjam.

c. Terciptanya administrasi pembukuan simpan pinjam yang tertib. Masingmasing kelompok sudah dapat mempraktekkan siklus akutansi koperasi dan menguasai cara menghitung pembagian SHU masing-masing anggota. Hal ini terbukti saat Rapat Anggota Tahunan (RAT) pengurus sudah bisa menyajikan laporan pertanggungjawaban yang lengkap, yang terdiri dari Laporan Neraca, laporan Rugi/laba atau SHU, Laporan arus Kas dan Laporan promosi anggota. Dalam laporan pertanggunjawaban pengurus juga telah dapat mencantumkan Rencana Kerja dan Rencana Anggaran.

\section{KESIMPULAN}

Berdasarkan hasil pelaksanaan kegiatan IbM yang telah dilakukan di Kelompok Simpan Pinjam Pedukuhan Singojayan dan Kelompok simpan Pinjam "Mawar" yang berada di Dusun Toglengan, Desa Sendangarum, Kecamatan Minggir, Kabupaten Sleman, seperti telah diuraikan pada bab terdahulu, maka dari kegiatan tersebut dapat disimpulkan hal-hal sebagai berikut:

1. Target kegiatan Penyuluhan tentang tata cara penyusunan AD/ART , dapat tercapai. Peserta pelatihan dapat mengetahui dan memahami tentang pedoman dan tatacara penyusunan anggaran Dasar dan Anggaran Rumah tangga

2. Target kegiatan Pelatihan Administrasi dan pembukuan kelompok dapat tercapai. Hal ini ditunjukkan dengan adanya peningkatan pengetahuan dan ketrampilan peserta dalam pengelolaan administrasi kelompok simpan pinjam dan 
pembukuan akuntansi simpan pinjam. Peserta juga telah memahami konsep dan mekanisme pengelolaan keuangan simpan pinjam. Peserta juga dapat menyusun laporan keuangan, baik laporan Neraca, laporan Hasil Usaha, laporan perubahan Modal dan laporan Arus Kas.

3. Kegiatan pelatihan manajemen kelembagaan \& Koperasi dapat meningkatkan pengetahuan pengurus tentang manajemen kelembagaan dan koperasi

4. Kegiatan Pelatihan \& Praktek komputermeningkatkan kemampuan dan ketrampilan peserta pelatihan dalam mengopersionalkan komputer dan dan dapat memanfaatkan software Ms office excel untuk pendukung pengelolaan KSP

5. Pelatihan kewirausahaan memberikan dan meningkatkan pengetahuan peserta pelatihan tentang kewirausahaan, sehingga menumbuhkan kreatifitas dan keinginan berwirausaha bagi peserta pelatihan.

\section{DAFTAR PUSTAKA}

Chaniago, Arifinal, 1982, “Perkoperasian Indonesia”, Bandung, Angkasa.

Garvin, Charles, 1986, “Contemporary Group Work . Prentice Hall Inc”, New Jersey, Englewood Cliff.

Gita Pertiwi,2010, “ Training Modul Konsep Dasar Kelompok ,Sumber dan Penggunaan Dana Kelompok,Pembukuan Keuangan Kelompok, colomadu, Griyan lama.

Gunardi, Seldadyo H. dkk, 1994, "Kredit untuk Rakyat, dari Mekanisme Arisan Hingga BPR”, Bandung, Akatiga..

Soekanto, Soerjono, 2005, “Sosiologi Suatu Pengantar”, Jakarta, CV Rajawali.

Sumodiningrat, Gunawan, 1997 “Pelayanan Kredit Untuk Masyarakat Lapisan Bawah”, Bappenas, dalam "Diskusi Ahli: Pemberdayaan dan Replikasi Aspek Finansial Usaha Kecil Di Indonesia”, Editor Erna Ermawati Chotim dan Juni Thamrin, 1997, Bandung, Yayasan Akatiga, PEP LIPI, Yayasan Mitra Usaha, The Asia Foundation . 
Verhagen, Koenraad, 1996, “ Self-Help Promotion, A Challenge to NGO

Community”, Cebemo/Royal Tropical Institute The Netherlands

Zainuddin, M, 1997. "Memberdayakan Ekonomi Rakyat Refleksi dan Replikasi Model-Model Finansial Untuk Usaha Kecil, Tinjauan Dari Sisi Penawaran” dalam "Diskusi Ahli: Pemberdayaan dan Replikasi Aspek Finansial Usaha Kecil Di Indonesia”, Editor Erna Ermawati Chotim dan Juni Thamrin, 1997, Bandung, Yayasan Akatiga, PEP LIPI, Yayasan Mitra Usaha, The Asia Foundation. 